\title{
Estimation of Stature from Anthropometric Dimensions of Hand and Foot in Egyptian Sample
}

\author{
Sahar M. Moustafa ${ }^{1}$
}

${ }^{1}$ Forensic Medicine and Clinical Toxicology Department, Faculty of Medicine, Suez Canal University, Egypt.

\begin{abstract}
Estimation of stature from incomplete or mutilated and decomposed skeletal remains has obvious importance in personal identification and considered as one of the "Big Four" parameters required to assist in the identification of an individual. Hand and Foot prints are the most valuable clues and may be the only evidence that be available at the crime scene in the form of latent impressions and stature prediction from these prints may support stature estimation of suspects made by eye-witnesses. The aim of the present study is to analyze the anthropometric relationship between hand and foot dimensions with stature in Egyptian population sample. Measurements of stature, hand and foot dimensions were taken from 97 adults (55 males and 42 females) aged from 21 to 45 years following the standard technique. The results revealed that values of all the measurements are statistically significant higher in males than in females and the standard error of estimate (SEE) was lowest using the measurement of foot length (SEE $\pm 4.26-3.78 \mathrm{~cm}$ for males and females respectively) followed by hand length (SEE \pm 5.14-3.94 cm for males and females respectively). Stature was significantly and positively correlated with all hand and foot dimensions while the foot length followed by hand length showed the highest correlation with stature which concluded that foot length and hand length are the most accurate measurements for estimating stature with high accuracy in both sexes.
\end{abstract}

Keywords Stature, hand dimensions, foot dimensions and Egyptian population.

$V^{\text {Introduct }}$ etion ith the increasing frequency of mass disasters and fatal assaults, identification of isolated extremities is the ultimate goal in the medico-legal investigations for victims' identity (Kanchan et al., 2010) to help in narrowing down the pool of the possible victim matches and provide useful clues to the identification of the individuals (pal et al., 2016). Stature is considered as one of the "Big Four" parameters required to assist with the individual identification especially when the other lines of evidence are corroborative (Ahemad and Purkait, 2011) and allow more definitive markers to be used for final identification confirmation (Ahmed 2013). Estimation of stature from incomplete, mutilated or decomposed skeletal remains has obvious importance in personal identification (Kanchan et al., 2008). Feet and hands' impressions are consider as the most valuable clues often, the only evidence that may be available at the crime scene. Stature prediction from these prints may support stature estimation of suspects made by eyewitnesses, hence come the importance of more researches on estimation of stature from hands and feet measurements which may help in medico-legal investigations (Paulis 2015). Population variations in anthropometric dimensions do exist (Abdel-Malek et al., 1990 \& Kumar et al., 2014) and a formula for one population does not necessarily yield reliable results for another due to inherent population variations that may be attributed to genetic and environmental factors. Thus, separate regression formulae should be developed in order to determine stature for each population group (De-Mendonca 2000).

\section{Aim of the Study}

Consequently, the aim of the present study is to analyze the anthropometric relationship between hand and foot dimensions with stature in Egyptian sample.

\section{Subjects and methods}

This study included 97 apparently healthy adult Egyptian volunteers (55 males and 42 females) from the guardians of pediatric patients in Elite Private Hospital in Riyadh City in Saudi Arabia Kingdom. The lower age limit was 21 years to be sure of the skeletal maturity and the higher limit is 40 as the stature starts to decline after the age of 40 years among white individuals (Galloway 1988). All the subjects were right handed as the existence of a significant asymmetry in upper limb dimensions associated with dominance (Raymond and Pontier, 2004 \& Auerbach and Ruff, 2006). The volunteers had no somatic diseases or any signs of trauma and persons with history of fractures, bone tumors, pathological lesions, left handed and manual workers subjects were excluded from the study to ensure normal bone evaluation (Sushi et al., 2010). It is worth mentioning that the thumb was not considered in any hand measurements because of its variable flexibility as compared to other fingers which are 
straight (Habib and Kamal, 2010). According to standard ethics drawn by the King Saud University Ethical Committee for human researches and after obtaining the informed consent from every one of study subjects, they were asked to fill a preliminary questionnaire about demographic characteristics like age, socio-economic status, place of birth and occupation. All the anthropometric measurements were taken independently on the left side of each individual in a good illuminated room by one observer in order to avoid inter-observer error (Krishan et al., 2010).

\section{The measurements:}

Stature: was measured in standing position with the subject barefooted in centimeter with a Harpenden portable stadiometer (Holtain Ltd, Crosswell, UK) according to Krishan and Sharma, (2007).

\section{Anthropometric hand dimensions (Figure 1):}

Wrist breadth (A-a) was measured with a digital sliding caliper (Mitutoyo, Japan) as the distance between the ulnar and radial styloid processes according to Ozaslan et al., (2006).

Hand breadth (B-b) was measured with a digital sliding caliper as the distance between the most lateral point on the head of the second metacarpal bone and the most medial point on the head of the fifth metacarpal bone according to Vallois (1965).

Hand length (C-c) was measured with a digital sliding caliper as the straight distance between the midpoint of the distal crease of the wrist to the most anterior projection of the skin of the middle finger according to Rastogi et al., (2008).

The measurements were recorded after instructing the subjects to sit and to place their left hands on a flat, hard horizontal surface with the thumb abducted and the other four fingers extended and adducted according to Rastogi et al., (2008).

\section{Anthropometric foot dimensions (Figure 2):}

Foot breadth (A-a) was measured with a digital sliding caliper as the distance between the point of the anterior epiphyses of the $1 \mathrm{st}$ metatarsal (the most prominent of the inner side of the foot) and the joint of the anterior epiphyses of the 5th metatarsal (the most prominent of the outer side) according to Krishan and Sharma, (2007).

Foot length (B-b) was measured with a digital sliding caliper as the distance from the most prominent part of the heel backward to the most distal part of the longest toe (2nd or $1^{\text {st }}$ ) according to Krishan and Sharma, (2007).

The digital sliding caliper is horizontally placed along the inner border of the foot and the measurement should be made on the standing subject, his right leg being slightly bent and drawn backward so that the body-rests mainly on the left foot according to Krishan and Sharma, (2007).

\section{Statistical analvsis:}

The data were analyzed using (SPSS) version 10 and regression formulae are developed for various combinations and stepwise regression analysis is based on the statistical significance level of $\mathrm{P}<0.05$ to reach the best estimate possible.

\section{Results}

Table (1) shows the descriptive statistics for stature and hand measurements in both sexes. Mean value, standard deviation and t-test values of hand length, hand breadth and wrist breadth are presented. The values of all measurements are higher in males than in females and these sex differences are statistically significant $(p<$ $0.01)$.

Table (2) shows the descriptive statistics for stature and foot measurements in both sexes. Mean value, standard deviation and t test values of foot length and foot breadth are presented. The values of all measurements are higher in males than in females and these sex differences are statistically significant $(\mathrm{p}<$ $0.01)$.

Table (3) shows that stature was significantly and positively correlated $(\mathrm{p}<0.001)$ with all hand and foot measurements. Hand length showed higher correlation coefficient than that of the other hand dimensions and foot length showed higher correlation coefficient than that of the other foot dimensions.

Table (4) shows the regression analysis to determine which hand or foot dimensions are best explained for variability in stature among the present population. It lists the linear regression equations for estimation of stature from measurements of hand and foot measurements in both sex. Regression formulae are accepted the most important formulas in determination of stature from anthropometric dimensions. Regression equations have been computed separately, for each sex and for each selected parameter of the hand and foot. A computer analysis of the data enabled the calculation of regression coefficients ' $a$ ' and ' $b$ ', where ' $a$ ' is the regression coefficient of the dependent variable i.e. stature and ' $b$ ' is the regression coefficient of the independent variable i.e. hand length, according to the formula, stature $=\mathrm{a}+\mathrm{bx}$; where $\mathrm{x}=\mathrm{a}$ measurement of hand or foot prints. The table also lists the standard error of estimate (SEE) along with linear regression equations for hand length, hand breadth, wrist breadth, foot length and foot breadth in both sexes. The SEE predicts the deviations of estimated stature from the actual stature. It ranges between \pm 4.26 (foot length) and \pm 6.13 (foot breadth) for males and between \pm 3.78 (foot length) and \pm 4.97 (hand breadth) for females. As the low value indicates the greater reliability in the estimated stature, foot length exhibits lower values in both sex and indicates that the foot length gives better reliability for prediction of stature. The regression coefficients were found to be statistically significant in all derived equations, while the coefficient of determination was greatest for the estimation of stature from hand length, hand breadth, wrist breadth and foot breadth.

Table (5) represents a comparison of actual stature and stature estimated from hand and foot measurements using linear regression equations. In both sexes, minimum and maximum estimated stature shows no greater variation with respect to the actual minimum and maximum stature and the mean estimated stature are close to actual stature (in $\mathrm{cm}$ ). 
Table (1): Descriptive statistics for stature and hands' measurements in both sexes.

\begin{tabular}{|c|c|c|c|c|}
\hline Parameter & Males & Females & \multicolumn{2}{|c|}{ t. test } \\
\cline { 4 - 6 }$(\mathbf{c m})$ & Mean \pm SD & Mean \pm SD & T & P \\
\hline Stature & $175.2 \pm 6.2$ & $161.2 \pm 5.8$ & 16.4 & 0.001 \\
& & & & \\
\hline Wrist breadth & $5.6 \pm 0.37$ & $4.87 \pm 0.33$ & 12.47 & 0.001 \\
\hline Hand length & $18.91 \pm 1.12$ & $17.3 \pm 0.88$ & 12.77 & 0.001 \\
\hline Hand breadth & $7.91 \pm 0.54$ & $6.98 \pm 0.37$ & 13.38 & 0.001 \\
\hline
\end{tabular}

Table (2): Descriptive statistics for stature and feet' measurements in both sexes.

\begin{tabular}{|c|c|c|c|c|}
\hline \multirow{2}{*}{ Parameter } & Males & Females & \multicolumn{2}{|c|}{ t. test } \\
\cline { 4 - 5 } & Mean \pm SD & Mean \pm SD & T & P \\
\hline Stature & $175.2 \pm 6.2$ & $161.2 \pm 5.8$ & 16.4 & 0.001 \\
\hline Foot breadth & $93.6 \pm 7.3$ & $86.8 \pm 5.63$ & 14.49 & 0.001 \\
\hline Foot length & $248.9 \pm 12.12$ & $226.3 \pm 8.83$ & 12.792 & 0.001 \\
\hline
\end{tabular}

All measurements (in $\mathrm{mm}$ ) and Stature (in $\mathrm{cm}$ )

Table (3): Correlation coefficient between stature and hands and feet measurements in both sexes.

\begin{tabular}{|c|c|c|}
\hline \multirow{2}{*}{ Variable } & \multicolumn{2}{|c|}{ Value of $\mathbf{~}$} \\
\cline { 2 - 3 } & Males & Females \\
\hline Wrist breadth & $0.533^{* * *}$ & $0.329^{* *}$ \\
\hline Hand length & $0.601^{* * *}$ & $0.621^{* * *}$ \\
\hline Hand breadth & $0.367^{* * *}$ & $0.421^{* * *}$ \\
\hline Foot length & $0.74^{* *}$ & $0.733^{* *}$ \\
\hline Foot breadth & $0.344^{* * *}$ & $0.34^{* *}$ \\
\hline
\end{tabular}

r: correlation coefficient. ** Significant at 0.01 level. *** Significant at 0.001 level.

Table (4): Linear regression equations for estimation of stature from hands and feet measurements in both sexes.

\begin{tabular}{|c|c|c|c|}
\hline $\begin{array}{c}\text { Males } \\
\text { Regression equations }\end{array}$ & \pm SEE & $\begin{array}{c}\text { Females } \\
\text { Regression equations }\end{array}$ & \pm SEE \\
\hline $\mathrm{S}=88.143+4.29 \mathrm{HL}$ & \pm 5.14 & $\mathrm{~S}=83.314+4.42 \mathrm{HL}$ & \pm 3.94 \\
\hline $\mathrm{S}=101.11+8.27 \mathrm{HB}$ & \pm 5.30 & $\mathrm{~S}=120.51+4.83 \mathrm{HB}$ & \pm 4.97 \\
\hline $\mathrm{S}=119.92+10.15 \mathrm{WB}$ & \pm 5.37 & $\mathrm{~S}=133.83+5.57 \mathrm{WB}$ & \pm 4.36 \\
\hline $\mathrm{S}=69.105+4.034 \mathrm{FL}$ & \pm 4.26 & $\mathrm{~S}=71.931+3.703 \mathrm{FL}$ & \pm 3.78 \\
\hline $\mathrm{S}=136.240+3.43 \mathrm{FB}$ & \pm 6.13 & $\mathrm{~S}=135.409+2.37 \mathrm{FB}$ & \pm 4.46 \\
\hline
\end{tabular}

$\boldsymbol{S}=$ stature, $\boldsymbol{H L}=$ hand length, $\mathbf{H B}=$ hand breadth, $\boldsymbol{W B}=$ wrist breadth, $\boldsymbol{F} \mathbf{L}=$ foot length, $\boldsymbol{F} \boldsymbol{B}=$ foot breadth. SEE: Standard Error of Estimate

Table (5): Comparison of actual stature and stature estimated from hands and feet measurements.

\begin{tabular}{|c|c|c|c|c|c|c|}
\hline $\begin{array}{c}\text { Estimated stature } \\
\text { using regression } \\
\text { equations for }\end{array}$ & $\begin{array}{c}\text { Males } \\
\text { estimated } \\
\text { stature }\end{array}$ & $\begin{array}{c}\text { Maximum } \\
\text { estimated } \\
\text { stature }\end{array}$ & $\begin{array}{c}\text { Mean } \\
\text { estimated } \\
\text { stature }\end{array}$ & $\begin{array}{c}\text { Minimum } \\
\text { estimated } \\
\text { stature }\end{array}$ & $\begin{array}{c}\text { Maximum } \\
\text { estimated } \\
\text { stature }\end{array}$ & $\begin{array}{c}\text { Mean } \\
\text { estimated } \\
\text { stature }\end{array}$ \\
\hline Hand length & 166.1 & 179.9 & 171.1 & 148.1 & 166.0 & 159.3 \\
\hline Hand breadth & 165.1 & 181.6 & 168.2 & 151.6 & 163.3 & 156.2 \\
\hline Wrist breadth & 166.5 & 180.5 & 169 & 150.6 & 163.7 & 157.6 \\
\hline Foot length & 166.1 & 184.0 & 171.2 & 149.4 & 166.0 & 159.5 \\
\hline Foot breadth & 163.0 & 176.7 & 171 & 152.5 & 162.1 & 158.7 \\
\hline Actual stature & 167.5 & 183.5 & 175.2 & 150.5 & 168.5 & 161.2 \\
\hline
\end{tabular}




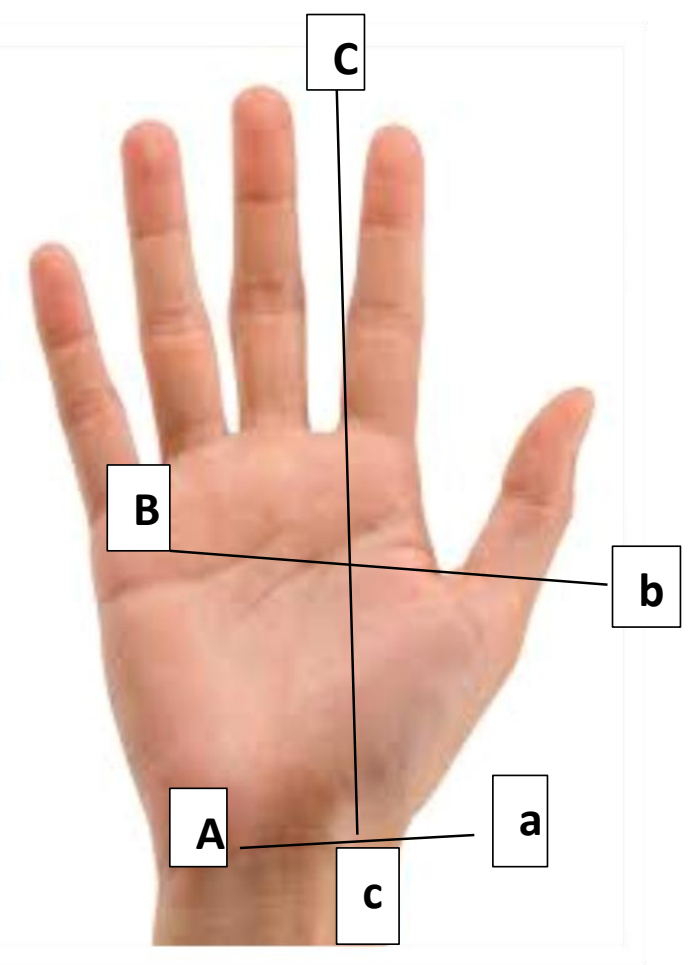

Figure 1: Human hand illustrating the landmarks of selected hand dimensions (Wrist breadth: A-a, Hand breadth: B-b and Hand length: C-c)
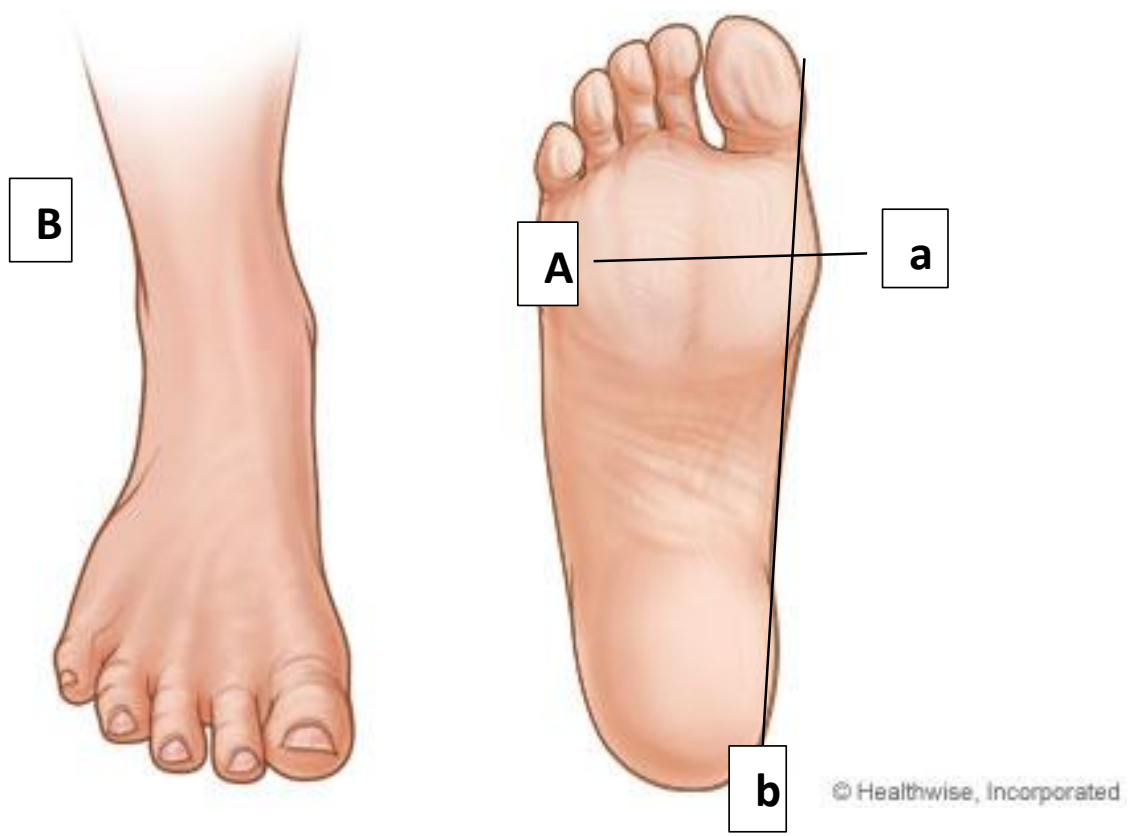

Figure 2: Human foot illustrating the landmarks of selected foot dimensions (foot breadth: A-a and foot length: B-b)

\section{Discussion}

The establishment of identity has an important judicial and medico-legal significance (Issa et al., 2016) while it is not uncommon to find parts of the body in mass disasters or where it is dismembered to estimate the identity of the victim (Kanchan and Kumar, 2010). Estimation of stature is one of the important initial steps during medico-legal analysis of skeletal remains and a major challenge in every country (Zaher et al., 2011).
Stature and body measurements differ among human populations (Sacngchaiya and Bunterngchit, 2004 \& Raxter et al., 2008 \& Zaher et al., 2011) as there are ethnic and geographical differences in body dimensions (Duyar and Pelin, 2003). It is worth mentioning that age, nutrition, environment, physical activity and living conditions may change the body dimensions (Khanapurkar and Radke, 2012 \& Krishan et al., 2012). 
Egypt is a vast country with a large population with multi-ethnic and multi-cultural sub-groups have their own variations. There may be inter-racial and intergeographical differences in body dimensions and thus differ in their relation to stature. A literature survey revealed that prediction of the stature from body dimension and formulation of standard equations from hand and foot dimensions especially among Egyptian population are scanty while earlier researches focused on stature prediction from isolated bones to help in personal identification in Egyptian population. Habib and Kamal, (2010) in a study for stature estimation from hand and phalanges lengths of Egyptians stated that bilateral variation was insignificant for all measurements and little finger measurements of male and distal phalanges of female fingers were not correlated with stature. Zaher et al. (2011) concluded that stature can be determined successfully using second and third metacarpals' dimensions among Egyptians and Aboul-Hagag et al. (2011) stated that there is a relationship between stature and hand measurements in both sexes and in both sides. The present study revealed that stature and all values of hand and foot measurements are statistically significant higher in males than in females which in consistency with the results of Aboul-Hagag et al. (2011) study which revealed the same conclusion and these results may be attributed to the early maturity of girls than boys so boys have two more years of physical growth (Krishan and Sharma, 2007). In assessing the accuracy of linear regression models in the present study, the standard error of the estimate (SEE) was lowest using the measurement of foot length ( $\mathrm{SEE} \pm 4.26-3.78 \mathrm{~cm})$ followed by hand length (SEE $\pm 5.14-3.94)$ which is in accordance with Krishan and Sharma (2007) study results which demonstrated that foot length is the most accurate measurement for estimating stature with high accuracy (SEE $\pm 4.38-3.53$ ) in both sexes and concluded that the foot length gives better reliability for prediction of stature. Paulis (2015) concluded that stature could be estimated from handprint measurements with SEE was the lowest in hand length $\pm 4.54 \mathrm{~cm}$ in male and $\pm 5.38 \mathrm{~cm}$ in female. [Rastogi et al. (2008) \& Habib and Kamal, (2010) \& Ahemad and Purkait, (2011)] results estimated that (SEE) was lowest using the measurement of hand length $[ \pm 3.65-5.04 \& \pm$ $4.54-5.48 \mathrm{~cm} \& \pm 4.64 \mathrm{~cm}-5.44 \mathrm{~cm}]$ respectively. The present results showed that stature was significantly positively correlated with all hand and foot dimensions while the foot length followed by hand length showed the highest correlation with stature and these results are consistent with previous studies that were undertaken on hand print and showed that the hand length was more useful in estimating stature than the hand breadth [(Ozaslan et al. (2012) \& Hossain et al. (2010)]. The present results revealed that the mean value estimates (mean estimated stature) are close to actual stature which in agree with Ishak et al. (2012) results which stated that stature prediction accuracy using hand measurements ranges from 4.74 to $6.53 \mathrm{~cm}$ and this is due to the fact that regression equations are calculated from measures of central tendency. The only precaution that must be taken into consideration in the present study is that the used formulae are applicable to the population from which the data have been collected due to genetic and environmental factors variation.

\section{Conclusion and Recommendations}

The results concluded that, the hand and foot measurements are considered as a prime criterion to stature estimation. The results showed significant correlations between stature of an individual and both hand and foot lengths. The concluded equations may be helpful to obtain approximate stature of an individual when there is difficulty in obtaining direct measurement such as in fragmented remains. The use of hand and foot measurements in stature estimation is still relatively novel and the applicability of that approach for use in medico-legal investigations should be evaluated by a wider anthropological and/or forensic community.

\section{Conflict of interest}

The author has no conflicts of interest to declare

\section{References}

Abdel-Malek AK, Ahmed AM, EL-Sharkawy SA et al., (1990): Prediction of stature from measurements. Forensic Science International; Elsevier Scientific Publishers Ireland Ltd. (46) 181- 187.

Aboul-Hagag KE, Mohamed SA, Hilal MA et al., (2011): Determination of sex from hand dimensions and index/ring finger length ratio in Upper Egyptians Egyptian Journal of Forensic Sciences; (1) 80-86.

Ahemad N and Purkait R (2011): Estimation of stature from hand impression: a nonconventional approach. J Forensic Sci.; (56), 706-710.

Ahmed AA (2013): Estimation of stature from the upper limb measurements of Sudanese adults. Forensic Sci. Int.; 228 (178):1-7.

Auerbach BM and Ruff CB (2006): Limb bone bilateral asymmetry: variability and commonality among modern humans, J. Hum. Evol.; (50): 203-218.

De-Mendonca MC (2000): Estimation of height from the length of long bones in a Portuguese adult population. Am J Phys. Anthropol.; (112) 3948.

Duyar I and Pelin C (2003): Body height estimation based on tibia length in different stature groups. Am J Phys Anthropol; 122: 23-27.

Galloway A (1988): Estimating actual height in the older individual, J. Forensic Sci.; (33): 126136.

Habib SR and Kamal N N (2010): Stature estimation from hand and phalanges lengths of Egyptians Journal of Forensic and Legal Medicine; (17)156-160.

Hossain S, Begum JA, A Banu ML et al., (2010): Prediction of stature from hand length and breadth - An anthropometric study on Christian Garo tribal Bangladeshi females. Bangladesh J Anatomy; 8 (1):21-27.

Ishak N I, Hemya N and Franklin D (2012): Estimation of stature from hand and handprint dimensions 
in a Western Australian population Forensic Science International; (216) 199.1-199.7.

Issa SY, Khanfour AA and Kharoshah M (2016): A model for stature estimation and sex prediction using percutaneous ulnar and radial lengths in autopsied adult Egyptians. Egyptian Journal of Forensic Sciences; 6, 84-89.

Kanchan T, Menezes RG, Moudgil R et al., (2008): Stature estimation from foot dimensions. Forensic Sci. Int. 179(241):1-5.

Kanchan J, Krishan K, Sharma A et al., (2010): A study of correlation of hand and foot dimensions for personal identification in mass disasters. Forensic Sci. Int. 199(1-3), 112.1-6.

Kanchan T and Kumar GP (2010):.Index and ring finger ratio - a morphologic sex determinant in South-Indian children. Forensic Sci. Med. Pathol.; 6: 255-260.

Khanapurkar S, Radke A (2012): Estimation of stature from the measurement of foot length, hand length and head length in Maharashtra region. Indian J Basic Appl Med Res.;1 (2):77-85.

Krishan K and Sharma A (2007): Estimation of stature from dimensions of hands and feet in a North Indian population. J. Forensic Leg. Med. (6):327-332.

Krishan k, Kanchan T and Di-Maggio JA (2010): A study of limb asymmetry and its effect on estimation of stature in forensic case work, Forensic Sci. Int.; (200): 181.1-5. Krishan K, Kanchan T, Menezes RG et al., (2012): Forensic anthropology case work essential methodological considerations in stature estimation, J. Forensic Nurs.; (8): 45-50.

Krishan K, Kanchan T and Asha N (2012): Estimation of stature from index and ring finger length in a North Indian adolescent population. J Forensic Leg Med 2012; 19:285-90.

Kumar P, Shahnawaz K and Varma G (2014): Study of estimation of stature by the length of femur. J Evol. Med. Dent. Sci; 3(12):3166-172.
Ozaslan A, Koc S, Ozaslan I et al., (2006): Estimation of stature from upper extremity, Mil. Med.; (171): 288-291.

Ozaslan A, Karadayi B, Kolusayin et al., (2012): Predictive role of hand and foot dimensions in stature estimation. Rom J Leg Med; 20:41-46.

Pal A, Sujaya D, Sengupta P et al., (2016): Estimation of stature from hand dimensions in Bengalese population, West Bengal, India, Egyptian Journal of Forensic Sciences; 6: 90-98.

Paulis MG (2015): Estimation of stature from handprint dimensions in Egyptian Population. Journal of Forensic and Legal Medicine; (34): 55-61.

Rastogi P, Nagesh KR and Yoganarasimha K (2008): Estimation of stature from hand dimensions of north and south Indians, Leg. Med.; (Tokyo) (10): 185-189.

Raxter MH, Ruff CB, Azab A et al., (2008): Stature estimation in Ancient Egyptians: a new technique based on anatomical reconstruction of stature. Am J. Phys. Anthropo.; 136 (2): $147-55$

Raymond M and Pontier D (2004): Is there geographical variation in human handedness? Laterality; (9) 35-51.

Sacngchaiya N and Bunterngchit Y (2004): Hand anthropometry of Thai female industrial workers. J KMITNB; 14(1):16-9.

Sushi K, Srivastava AK and Sahai MB et al., (2010): Estimation of stature by anthropometric examination of forearm and hand. $\mathrm{J}$ Indian Acad Forensic Med.; 32(1):62-65.

Vallois HV (1965): Anthropometric techniques, Curr. Anthropol.; (6)127-144.

Zaher JF, El-Ameen NF and Seedhom AE (2011): Stature estimation using anthropometric measurements from computed tomography of metacarpal bones among Egyptian population. Egypt J Forensic Sci; 1: 103-108. 


\section{الملخص العربي}

\section{تقدير طول القامة من الأبعاد الأنثروبومترية لليد و القدم في عينة من المصريين}

\section{سحر محمد علي مصطفى'}

إن تقدير طول القامة بإستخدام البقايا الغير مكتملة أو المشوهة والمتحللة للهيكل العظمي له أهمية واضحة في الإستعراف ويعتبر

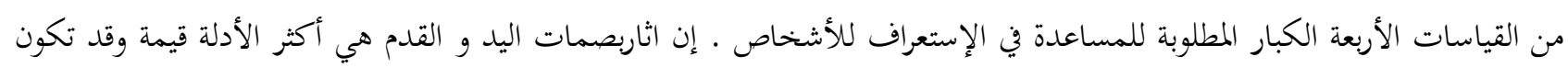

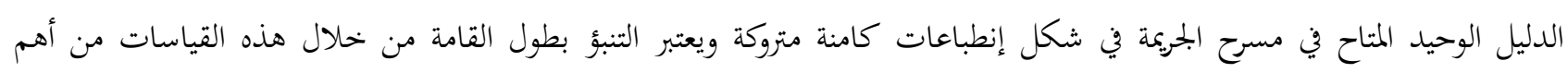
الدعامات لتقدير طول المشتبه بهم من قبل شهود العيان. كان الهدف من هذه الدراسة هو تحليل العلاقة الأنثروبومترية بين طول القامة و قياسات أبعاد اليد والقدم في عينة من الأشخاص المصريين. و قد خضع المشاركين في الدراسة لقياسات الطول و أبعاد اليد والقدم

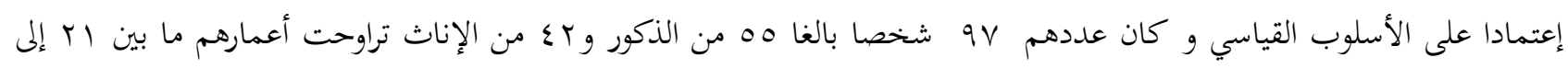

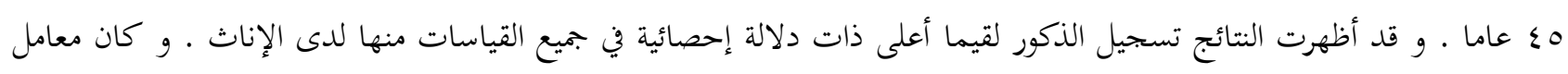

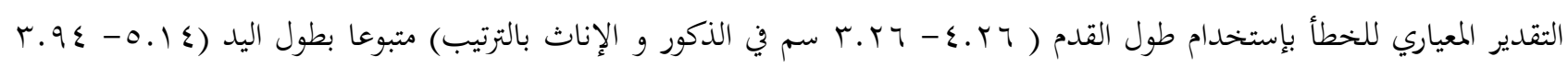

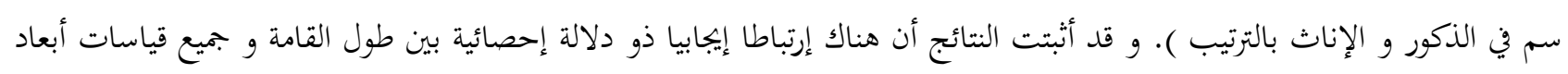

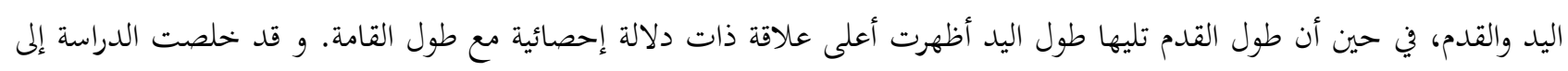
أن طول القدم وطول اليد هما المقياسان الأكثر دقة لتقدير طول القامة في كلا الجنسين. 